\title{
SAKAI SAMBAIAN : SISTEM GOTONG ROYONG DI LAMPUNG TIMUR
}

\author{
Sakai Sambaian: Mutual Help in East Lampung
}

\author{
Oleh Ani Rostiyati
}
Balai Pelestaran Sejarah Dan Nilai Tradisional Bandung
Jl. Cinambo No. 136 UjungBerung - Bandung
E-mail:anirostiyati@yahoo.com

\begin{abstract}
Abstrak
Di Lampung Timur tepatnya di Desa Negara Nabung Kecamatan Sukadana, masyarakatnya masih memegang kuat nilai-nilai kegotongroyongan yang dijalankan dalam kehidupan sehari-hari, baik gotong royong tolong-menolong maupun gotong royong kerja bakti. Masyarakat Negara Nabung menjalankan aktivitas gotong royong tolong-menolong dalam kehidupan sehari-hari, baik di bidang mata pencaharian hidup, kemasyarakatan, dan pelaksanaan upacara adat. Di bidang mata pencaharian, mereka melakukan gotong royong di bidang pertanian yakni di ladang (kebun) dan sawah. Selain bidang pertanian, gotong royong juga dilakukan dalam bidang kemasyarakatan yakni membantu dalam mendirikan rumah, kematian, dan jika ada musibah seperti sakit, kebakaran, kecelakaan dan lain-lain. Di bidang adat, masyarakat tolong-menolong dalam pelaksanaan upacara adat, misalnya dalam upacara perkawinan, kelahiran, dan pemberian gelar (cakak pepadun). Gotong royong kerja bakti juga dilakukan untuk kepentingan umum seperti memperbaiki jalan, mesjid, irigasi, dan balai desa.

Namun demikian, tidak dipungkiri pada masa sekarang bentuk gotong royong mengalami perubahan akibat dari perkembangan teknologi, industrialisasi, dan modernisasi. Terlepas dari perubahan yang terjadi, sikap gotong royong pada masyarakat Negara Nabung masih cukup kuat melekat. Hal itu disebabkan di Desa Negara Nabung terdapat prinsip sakai sambaian, salah satu prinsip hidup gotong royong di Lampung. Sakai sambaian adalah nilai budaya penting pada masyarakat Negara Nabung yang sudah menjadi pedoman hidup sehari-hari
\end{abstract}

Kata kunci: gotong royong, aktivitas, pandangan hidup masyarakat Negara Nabung Lampung Timur.

\begin{abstract}
Desa (village) Negara Nabung, Kecamatan (district) Sukadana in East Lampung holds strong values of togetherness (gotong-royong), either in their daily social life or in traditional ceremony. This kind of value has gradually faded due to very fast development in technology, industrialization and modernization. Fortunately, Desa Negara Nabung has a principle called sakai sambaian that helps their bond strong. Sakai sambaian is
\end{abstract}


their guidance in their daily social life, e.g. in erecting new houses, mending roads, and conducting wedding ceremony.

Keywords: togetherness, activities, way of life of Negara Nabung community in East Lampung.

\section{A. PENDAHULUAN}

Gotong royong sudah menjadi nafas kehidupan bagi masyarakat Indonesia terutama mereka yang tinggal di pedesaan, semua aktivitas dilandasi dengan semangat gotong royong. Bila dikaitkan dengan pembangunan, maka gotong royong ini mempunyai peran penting untuk menunjang keberhasilan pembangunan. Apabila pembangunan diartikan sebagai suatu proses perubahan yang terarah dan terencana, hal ini berarti pembangunan akan berusaha untuk mengubah keadaan lebih baik. Pembangunan tidaklah berarti perubahan itu sendiri, karena perubahan dapat diartikan memelihara apa yang ada, membangun apa yang tidak ada, memperbaiki apa yang rusak, termasuk di dalamnya kebudayaan. Pembangunan mungkin dapat menggeser nilai-nilai budaya yang sudah lama menjiwai masyarakat atau sebagian besar anggota masyarakat. Proses ini tidak dapat dilepaskan dari peranan para pelopor pembangunan. Keberhasilan dari pelopor pembangunan senantiasa bergantung pada keberhasilan dalam membangun komunikasi yang baik dengan masyarakat yang menjadi sasaran.

Apabila gotong royong dan kerja sama dihubungkan dengan pembangunan, faktor gotong royong menunjang proses pembangunan. Apabila pelopor pembangunan berhasil membangun komunikasi dan melibatkan masyarakat, menandakan bahwa pelopor perubahan dapat memanfaatkan partisipasi masyarakat. Dengan demikian gotong royong (dalam arti nilainya) yang telah membudaya bisa dipergunakan untuk kepentingan proses pembangunan. Walau-pun kegiatan gotong royong dikhawatirkan mulai melemah, ini tidak berarti gotong royong itu punah, melainkan yang berubah adalah bentuknya. Nilai-nilai kerja sama tolong-menolong masih akan ada di dalam masyarakat. Dengan demikian dapat dikata-kan bahwa nilai gotong royong merupakan modal sosial dalam proses pembangunan. Apabila para pelopor pembangunan tidak dapat menerapkan faktor tersebut dan proses pembangunan tetap dijalankan, ini berarti menggunakan metode paksaan. Akibatnya, pembangunan tidak tercapai. Komunikasi dengan masyarakat dan nilai-nilai yang telah membudaya tidak dimanfaatkan sebagai alat untuk mencapai pembangunan, padahal gotong royong bisa mendukung dan merupakan modal sosial dalam tercapainya pembangunan.

Gotong royong di Lampung seperti tertuang pada salah satu prinsip hidupnya yang disebut sakai sambaian, bisa dijadikan sebagai modal sosial untuk pembangunan. Sakai (sesakai) artinya tolong-menolong di antara sesama silih berganti dan sambaian (sesambai) artinya bergotong royong dalam mengerjakan sesuatu yang besar dan berat. Sakai sambaian (gotong royong) adalah salah satu unsur dalam pandangan hidup orang Lampung yang dinilai sebagai sesuatu yang baik, yang perlu dihadirkan dalam relasi sosial.

Namun demikian, sekarang ini ada kekhawatiran berkaitan dengan adanya indikasi atau gejala memudarnya serta perubahan persepsi terhadap nilai-nilai budaya lokal dan karakteristik budaya pada sebagian generasi muda yang kurang memahami adat istiadat dan nilai-nilai budaya Lampung. Sebenarnya indikasi ini juga terjadi pada masyarakat Indonesia pada umumnya, terutama di perkotaan, nilai-nilai kegotongroyongan mulai melemah. Adanya proses industrialisasi, pendidikan, dan modernisasi, dikhawatirkan mempengaruhi perubahan nilai budaya gotong royong tersebut.

Sistem gotong royong merupakan organisasi sosial yang di dalamnya mengan- 
dung makna kerja sama di antara anggota kelompok masyarakat. Secara jelas Koentjaraningrat mengatakan bahwa kerja sama timbul apabila orang mempunyai kepentingan yang sama dan adanya organisasi atau orang-orang yang mengorganisasikan. Bentuk kerja sama tradisional itu disebut dengan nama gotong royong, yang berarti sebagai bentuk kerja sama untuk mencapai tujuan tertentu dengan asas timbal balik (resiprositas) untuk mewujudkan adanya keteraturan sosial dalam masyarakat, baik yang dilandasi spontanitas, pamrih pribadi, atau karena memenuhi kewajiban sosial. Hal ini berkaitan dengan sifat manusia yang disebut sebagai makhluk sosial, artinya adalah manusia tidak dapat hidup tanpa berkelompok.

Menurut Rudito, Bambang (2011: 5), organisasi sosial merupakan sebuah manajemen budaya yang mengatur anggota kelompok sosial untuk melakukan aktivitas tertentu dengan cara tertentu yang disepakati oleh kebudayaan yang berlaku. Organisasi sosial ini dapat dijabarkan dalam beberapa pranata sosial, seperti religi, ekonomi, kekerabatan, kesenian, dan bahasa. Salah satu unsur organisasi sosial adalah yang beraktivitas sebagai gotong royong. Gotongroyong sendiri dapat dibagi ke dalam beberapa bentuk, seperti tolong-menolong, kerja bakti, dan saling membantu.

Gotong royong tolong-menolong bisanya berkaitan dengan persoalan kehidupan individu dalam masyarakat secara pribadi dalam kaitannya dengan pranata sosial yang berlaku. Mereka melakukan kegiatan kerja sama berkaitan dengan kehidupan individu lainnya (balance reciprocity), seperti dalam membuat rumah, pertanian, dan perkawinan. Gotong royong saling membantu adalah melakukan kegiatan membantu individu lain tanpa mengharapkan balasan, seperti kematian, sakit, dan musibah lainnya. Gotong royong saling membantu bisa saja berupa barang yang bermakna religius (zakat, sedekah dsb.). Adapun gotong royong kerja bakti yakni gotong-royong yang dilakukan oleh anggota masyarakat dalam usaha untuk kepentingan bersama, seperti untuk kebersihan kampung atau desa, upacara yang berkaitan dengan keagamaan di kampung, mendirikan masjid, dan memperbaiki jalan desa.

Menurut Koentjaraningrat (1984:6), gotong royong adalah salah satu unsur (aktivitas) dalam organisasi sosial yang merupakan suatu konsep atau nilai kebersamaan (kerja sama) dan merupakan sifat positif dalam mentalitas masyarakat. Gotong royong merupakan cerminan dari manusia yang merupakan makhluk hidup sosial tidak bisa hidup sendiri, karena dikelilingi oleh sistem sosial dan komunitas yang selalu terikat. Jika gotong royong dilihat sebagai kebudayaan, di dalamnya terdiri atas 3 wujud, yakni gotong royong bisa dilihat sebagai sistem ide (nilai, norma, aturan), sistem sosial (aktivitas kerja sama atau tindakan), dan hasil tindakan/aktivitas dari gotong royong (terwujudnya jalan, perbaikan rumah).

Koentjaraningrat juga membedakan antara gotong royong tolong-menolong dan gotong royong kerja bakti. Adapun menurut Putra, Heddy Shri Ahimsa (2004: 47), gotong royong adalah salah satu dari unsur organisasi sosial yang merupakan aktivitas kerja sama. Organisasi sosial kerja sama (gotong royong) biasanya ditujukan untuk mengatasi masalah-masalah umum yang dihadapi para anggotanya, dan kegiatan tersebut biasanya hanya dapat diselenggarakan dengan bantuan banyak orang.

Adapun yang menjadi lokasi penelitian ini adalah Desa Negara Nabung, Kecamatan Sukadana, Kabupaten Lampung Timur. Alasan pemilihan lokasi adalah karena di daerah tersebut masih mengenal aktivitas gotong royong. Selain karena memiliki prinsip hidup yang menjunjung tinggi harga diri dan sifat manusia yang memiliki nilai budaya luhur (piil pesenggiri); juga ada aturan adat yang kuat yakni penyimbang (pemimpin adat) yang berperan dalam menggerakkan masyarakat untuk bergotong royong; dan sistem kekerabatan yang berdasarkan patrilineal. Sistem patrilineal berdampak terhadap kegiatan gotong royong, karena kaum laki-laki wajib 
membantu semua keluarga atau kerabatnya jika memerlukan bantuan untuk memecahkan persoalan hidup. Sistem Patrilineal di masyarakat Negara Nabung, mengharuskan kaum laki-laki melaksanakan kegiatan gotong royong di lingkungan keluarga maupun masyarakat.

Adapun tujuan dari penelitian tersebut adalah untuk mendata gotong royong apa saja yang dilakukan oleh masyrakat Negara Nabung dan mengkaji bagaimana prospek gotong royong ke depan dikaitkan dengan nilai budaya kerja sama yang penting bagi pembangunan karakter bangsa; dan jika ada perubahan atau pergeseran dalam aktivitas gotong royong yang dilakukan dulu dan sekarang, apa saja yang berubah dan apa penyebabnya.

Secara umum identifikasi dan kajian ini dibatasi oleh dua hal. Pertama, identifikasi kegiatan gotong-royong, tolongmenolong, meliputi bidang ekonomi dan mata pencaharian hidup, bidang teknologi, perlengkapan hidup, dan bidang kemasyarakatan. Kegiatan atau aktivitas kerja bakti meliputi bidang ekonomi dan bidang kemasyarakatan. Kedua, kajian tentang kegiatan gotong royong apa saja yang masih dilaksanakan atau tidak dilaksanakan, dan jika terjadi pergeseran atau perubahan apa penyebabnya, serta bagaimana prospek ke depannya. Adapun lokasi penelitian di Desa Negara Nabung, Kecamatan Sukadana, Kabupaten Lampung Timur.

Metode yang digunakan dalam penelitian ini adalah deskritif kualitatif untuk memperoleh data yang lengkap dan menyeluruh tentang kegiatan gotong royong, yakni dengan melakukan wawancara mendalam (indepth interview) dan observasi. Melalui metode wawancara mendalam diharapkan akan diperoleh data kualitatif mengenai aktivitas gotong royong dan mekanisme hubungan sosial yang terjadi. Oleh karena itu, pendekatan penelitian yang dipakai adalah pendekatan kualitatif, yakni lebih menekankan pada analisis terhadap dinamika hubungan antarfenomena yang diamati dengan menggunakan logika ilmiah. Bila dilihat dari kedalaman analisisnya, jenis penelitian ini bersifat deskriptif yakni menganalisis dan menyajikan fakta secara sistematik sehingga mudah dipahami
(Saifuddin, 1997:7). Alasan menggunakan metode deskritif kualitatif, karena data yang dicari adalah berupa aktivitas gotong royong, pandangan hidup dan nilai budaya yang melatarbelakangi, sehingga tidak bisa dikategorikan atau diklasifikasikan dalam bentuk angka secara kuantitatif.

\section{B. HASIL DAN BAHASAN \\ 1. Gambaran Umum Desa Negara Nabung}

Desa Negara Nabung, yang menjadi lokasi penelitian ini adalah salah satu desa di Kecamatan Sukadana, Kabupaten Lampung Timur. Jarak dari Kecamatan Sukadana ke tempat tersebut kurang lebih $20 \mathrm{~km}$ dan dari Kabupaten Lampung Timur sekitar $30 \mathrm{~km}$. Masyarakat Negara Nabung adalah masyarakat yang tinggal di darat yang beradat pepadun. Masyarakat Lampung terdiri atas 2 adat yakni masyarakat pesisir (pantai) beradat saibatin dan masyarakat darat beradat pepadun. Seperti halnya masyarakat Lampung, masyarakat Negara Nabung masih kuat dalam melaksanakan kegiatan gotong royong, baik di bidang pertanian, pelaksanaan upacara adat, kematian, pembuatan rumah, dan kerja bakti untuk kepentingan umum. Luas wilayah Negara Nabung kurang lebih 5.000 meter persegi, terdiri atas 7 dusun, yakni Dusun Karang Agung, Karang Siyo, Karang Jaya, Karang Anyar, Karang Sari, Karang Rejo, dan Karang Anom.

Adapun batas wilayah Desa Negara Nabung: sebelah utara berbatasan dengan Desa Bumi Ayu; sebelah timur berbatasan dengan Desa Terbanggi Marga; sebelah barat berbatasan dengan Desa Rajabasa Batanghari; dan sebelah timur berbatasan dengan Desa Terbanggi Marga. Desa Negara Nabung bersuhu $28^{\circ}-32^{\circ} \mathrm{C}$ dengan curah hujan 2.000/3.000 $\mathrm{mm}$ dan kelembaban udara $120 \mathrm{ppm}$. Sebagian besar penduduk Negara Nabung bekerja sebagai petani. Mayoritas dari mereka bertani di ladang dan kebun, dan hanya sebagian kecil yang bertani di sawah, namun karena pengaruh masuknya transmigran dari Jawa lama kelamaan mengenal pertanian sawah.

Penduduk Desa Negara Nabung pada tahun 2011 tercatat 3.062 jiwa, terdiri atas 1.658 laki-laki dan 1.404 perempuan, serta terbagi menjadi 610 KK. Menurut 
pendidikan, penduduk Negara Nabung yang tidak tamat SD berjumlah 734 jiwa, tamat SD berjumlah 995 jiwa, tamat SLTP berjumlah 576 jiwa, dan sarjana berjumlah 40 jiwa. Kesadaran tentang pentingnya pendidikan, terutama pendidikan dasar 9 tahun baru terjadi beberapa tahun ini sehingga jumlah lulusan SD dan SLTP mendominasi peringkat pertama.

Masyarakat Negara Nabung hampir semua memeluk agama Islam, meskipun masih juga terdapat kepercayaan terhadap makhluk-makhluk halus. Bangunan desa seperti masjid, balai adat (sesat) pada umumnya terletak di tengah-tengah kampung, dan biasanya berdekatan dengan rumah kerabat pemimpin adat (penyimbang). Bangunan rumah kepala adat mengelompok bersama-sama dengan rumah-rumah anggota kerabatnya.

Desa Negara Nabung saat ini tidak memiliki gedung SLTP dan SLTA, karena jumlah siswa sedikit dan sudah terakomodasi oleh SLTP dan SLTA desa terdekat. Pasar desa tidak ada sehingga untuk memenuhi kebutuhan sehari-hari masyarakat biasanya datang ke pasar tradsional yang ada di Kecamatan Sukadana. Secara umum prasarana dan sarana yang ada di desa masih kurang memadai, mengingat jumlah penduduk sudah 3.062 jiwa. Visi Desa Negara Nabung " Mewujudkan Desa Negara Nabung Menjadi Desa Mandiri Melalui Bidang Pertanian dan Industri Kecil". Selama bertahun-tahun Desa Negara Nabung menyandang gelar sebagai desa kategori Desa Merah atau miskin. Sebuah sebutan yang sangat tidak membanggakan, padahal sumber daya yang ada cukup memadai, hanya penanganannya kurang maksimal. Saat ini, Desa Negara Nabung memperbaiki dan menambah sarana dan prasarana yang dibutuhkan untuk meningkatkan SDM melalui pendidikan formal maupun informal. Usaha yang dilakukan adalah bekerja sama dengan petugas penyuluh lapangan untuk meningkatkan hasil pertanian, usaha pertanian, meningkatkan dan mengelola pendapatan asli desa, serta mewujudkan pemerintahan yang baik dan bersih melalui pelaksanaan otonomi daerah.

\section{Aktivitas Gotong Royong}

Masyarakat Negara Nabung membedakan kegiatan gotong royong tolong-menolong dalam dua kategori, yakni sakai dan Abir. Sakai artinya tolongmenolong di antara sesama secara bergantian. Kerja sama tolong-menolong dalam jenis pekerjaan yang sama sehingga setiap anggota akan memperoleh giliran waktu yang sama pula, seolah ada harapan untuk mendapatkan balasan dan dilakukan dengan anggota yang lebih sedikit. Adapun yang dimaksud dengan abir adalah kerja sama tolong-menolong dalam pekerjaan yang dilakukan oleh atau dengan anggota yang lebih banyak dan tidak kelihatan pamrihnya. Maksudnya tidak terdapat kewajiban untuk mengerjakan pekerjaan yang sama dari mereka yang pernah menolong tersebut. Abir merupakan istilah lokal masyarakat Desa Negara Nabung yang berarti bergotong royong tanpa adanya perjanjian, imbalan, dan tanpa pamrih serta merupakan kesadaran komunal. Sakai biasanya dilakukan dalam gotong royong tolong-menolong di bidang pertanian, membangun rumah, ekonomi, dan adat. Sedangkan abir adalah gotong royong kerja bakti yakni untuk kepentingan umum.

Dalam bidang mata pencaharian, masyarakat Negara Nabung melakukan gotong royong tolong-menolong (sakai) di bidang pertanian yakni di ladang (kebun) dan sawah. Kegiatan gotong royong pertanian di ladang antara lain merancang (membuka hutan), ngusi (menebas semak belukar), nyuah (pembakaran), tajuk nugal (membuat lubang dan menyebarkan benih), dan ngetas (menuai). Adapun kegiatan gotong royong di sawah antara lain melakukan buakhhoh, yakni melembutkan tanah dengan hewan kerbau tapi sekarang dengan traktor; nanom yakni kegiatan menanam padi; ngegetas (menuai padi); dan batok buatot mengangkut padi ke lumbung. 
Gotong royong tolong-menolong di bidang pertanian dimulai dari kegiatan merancang. Setelah itu ngusi, yaitu menebas semak belukar yang tumbuh di bawah pohon dan nyuakh, yaitu kegiatan menebang pohon dan membakar dahan atau ranting serta pohon-pohon yang telah ditebang. Najuk Nugal, yaitu pekerjaan membuat lubang dan menaburkan benih, kemudian dilanjutkan dengan ngegetas yaitu menuai atau mengambil hasil ladang. Tolong-menolong dalam bercocok tanam di ladang dapat dilihat dari kelompok yang terlibat. Secara umum kelompok yang terlibat dalam kegiatan tersebut adalah orang dewasa yang sudah berkeluarga. Namun untuk pekerjaan yang agak ringan melibatkan anak bujang gadis artinya kelompok laki-laki maupun perempuan yang belum berkeluarga. Orang dewasa yang terlibat dalam kegiatan tersebut adalah kegiatan menebang, sedangkan dari orang dewasa dan bujang gadis yang terlibat secara abir adalah kegiatan Nugal - Najuk (kegiatan membuat lubang dan menabur benih). Gotong royong tolong menolong bercocok tanam di ladang yang terlibat antara 10 sampai 20 orang, sedangkan pekerjaan yang tidak memerlukan orang banyak biasanya hanya dilakukan 2 sampai 5 orang.

Secara umum peserta tidaklah terbatas pada ada atau tidaknya hubungan keluarga (baik karena hubungan darah maupun hubungan perkawinan), tetapi diikuti juga oleh mereka yang bukan keluarga, bahkan bujang gadis dari luar kampung juga turut serta. Penyebab utamanya adalah kegiatan ini juga menjadi wadah atau tempat untuk memperoleh jodoh.

Dalam pengerjaan di ladang terdapat ketentuan tentang adanya kewajiban dari tiap warga untuk mengerjakan pekerjaan yang sama atau sejenis. Dengan demikian, faktor kehadiran dalam melaksanakan pekerjaan merupakan suatu kewajiban. Namun tidak ada sanksi bagi warga yang tidak hadir pada waktu melakukan gotong royong. Dalam kegiatan kerja bakti secara abir, ketentuan yang demikian tidak ada, karena dalam abir tujuannya adalah untuk kepentingan umum misalnya membangun atau memperbaiki jalan, mesjid, balai desa, membersihkan makam dan sungai. Dalam kegiatan gotong royong secara sakai ini tidak menyediakan perlengkapan khusus. Namun, pengundang secara khusus menyediakan makanan ala kadarnya sebagai suguhan untuk orang banyak. Pada umumnya pekerjaan yang dilakukan secara sakai, dilaksanakan hanya dalam satu hari, kalau pekerjaan itu belum selesai seluruhnya biasanya akan dikerjakan sendiri oleh empunya ladang dan kemungkinan untuk dilakukan lagi pada hari berikutnya.

Adapun kerjasama gotong royong tolong-menolong di sawah dilakukan beberapa tahap, yakni batok buakhoh (membajak) dilakukan oleh pemilik kerbau, sedangkan batok nanom dlakukan oleh orang dewasa laki-laki, sedangkan batok ngegetas (menuai padi) pesertanya terdiri atas para wanita dan laki-laki dewasa serta batok boatot pesertanya hanya terdiri atas para bujang (laki-laki). Pelaksanaan ini bermula dari pemberitahuan kepada para tetangga atau sanak famili maupun warga kampung oleh pemilik sawah, sebagai permohonan bantuan dengan menyatakan waktu dan tempatnya. Kegiatan batok buakhoh biasanya dilakukan pada pagi hari mulai pukul 06.00 sampai dengan pukul 08.00 untuk menghindari terik matahari atau dilaksanakan pada sore hari pukul 16.00 sampai pukul 18.00. Untuk menuai padi biasanya dilakukan oleh para ibu yang mendapatkan bagi hasil, bahkan sekarang sudah menggunakan upah kerja. Dahulu upah kerja dikenal dengan sistem sakai, yakni mendapatkan bentuk pinjaman gabah yang nantinya akan dibayar dengan jumlah yang sama.

Selain bidang pertanian, gotong royong tolong-menolong juga dilakukan dalam bidang kemasyarakatan, yakni mereka membantu dalam mendirikan rumah dan perbaikan rumah, kematian, dan jika ada musibah (sakit, kebakaran, kecelakaan dan lain-lain). Dalam bidang adat, masyarakat Negara Nabung saling menolong dalam pelaksanaan upacara adat, misalnya dalam upacara perkawinan (nyani kubu 'membuat tarup', ngerang 'menumbuk padi', tandang 'mencari keperluan pesta di hutan', melawai 'mencari ikan', memasak, dan ngabebak 
kubu 'membongkar tarup'), kelahiran, dan pemberian gelar (cakak pepadun).

Dalam pembuatan atau perbaikan rumah bisa dilihat dari dua segi yakni tujuan dan kelompok masyarakat yang ikut membantu. Kegiatan awal adalah ngelandau kayu, yaitu kegiatan kerjasama tolongmenolong dalam mengumpulkan dan menghanyutkan kayu melalui sungai atau laut (dahulu). Namun sekarang hal itu jarang dilakukan, mereka lebih banyak membeli atau menebang pohon jati di kebun sendiri. Cukup banyak warga Negara Nabung yang menanam sendiri pohon jati dan kira-kira berusia 10 sampai 15 tahun pohon tersebut ditebang untuk membuat rumah anak cucu. Masyarakat yang ikut serta dalam kegiatan tersebut adalah laki-laki dewasa kira-kira 10 sampai 15 orang. Namun demikian, kehadiran para wanita juga diperlukan yakni untuk menyiapkan makanan. Walaupun tidak ada pembatasan yang tegas, namun para peserta terdiri atas para kerabat dan tetangga para kaum kerabat dan tetangga. Dalam mendirikan dan membongkar rumah, terdapat ketentuan khusus mengenai waktu pada hari dan bulan yang baik. Sebelum mendirikan rumah diadakan upacara ngejunjungi, yakni memohon kepada Tuhan YME dan leluhur agar dalam membangun atau membongkar rumah diberi keselamatan dan keberhasilan.

Pada dasarnya sebelum kegiatan menebang kayu atau ngelandau kayu, terlebih dahulu dilaksanakan pemberitahuan kepada kaum kerabat dan tetangga, baik yang ada di kampungnya maupun di luar kampungnya. Bahan bangunan tersebut dibawa dengan gerobak atau dipikul bersama-sama. Kegiatan tolong-menolong mendirikan rumah akan dilaksanakan apabila bahan mendirikan rumah tersebut telah siap. Setelah ditentukan hari dan bulan yang baik dan adanya pemberitahuan sebelumnya, maka para peserta berdatangan berjumlah kurang lebih 10 orang laki-laki dewasa. Pagi hari pekerjaan ini mulai dilakukan dengan mendirikan tiang tengah dan diperkirakan pukul 08.00 telah selesai dipasang dan peserta abir beristirahat untuk minum pagi. Setelah itu dilakukan upacara ngejunjungi, yakni menaikkan setandan pisang mas yang ranum, padi, kelapa, tahu, dan kendi yang berisikan air.

Menurut kebiasaan masyarakat di Desa Negara Nabung, setiap mendirikan rumah selalu diawali dengan melaksanakan upacara adat yang disebut dengan sedekah bumi atau ngajalang, bertujuan untuk memohon keselamatan kepada Tuhan dan leluhur. Pelaksanaan upacara dilakukan pagi hari, dipimpin oleh ulama, ketua adat (penyimbang), keluarga, dan tetangga dekat. Para ibu dan gadis menyiapkan makanan yang disebut dengan punar terdiri dari atas ketan kuning yang dicampur dengan kelapa muda, ayam panggang, dan dupa kemenyan. Hidangan ini nantinya akan dibagikan kepada warga untuk dimakan bersama. Setelah upacara selesai, pekerjaan dilanjutkan secara bergotong royong dengan dibantu oleh beberapa tukang ahli bangunan dan kayu.

Mendirikan rumah biasanya dilakukan secara beberapa tahap yakni pertama, proses musyawarah baik tentang waktu, bahan, peralatan, dan pengerahan tenaga kerja. Kedua, cara betegi (pembuatannya) yakni mempersiapkan tiang bawah yang diganjal dengan batu, membuat tiang duduk, memasang alang melintang, terakhir adalah memasang reng dan genteng. Pemasangan kasau dan reng ini memakan waktu yang lama, karena harus teliti. Tengah hari para peserta melakukan istirahat untuk makan siang. Makanan yang sudah dimasak ibuibu biasanya dikirim oleh para bujang gadis dengan menggunakan alat angkut gerobak yang ditarik sapi. Usai makan siang dilanjutkan dengan pembacaan doa agar rumah yang didirikan diberkahi oleh Tuhan, para penghuninya mendapatkan kesehatan dan keselamatan. Setelah istirahat dan sembahyang dluhur, pekerjaan dilanjutkan kembali, tetapi bagi peserta yang akan pulang, terutama bagi mereka yang tinggal di luar kampung diperkenankan. Pekerjaan akan dilanjutkan kembali pada sore hari dengan memasang atap genteng atau seng. Makan- 
an sore hari biasanya disajikan bubur yang disebut kinca (krui).

Kegiatan membongkar rumah, biasanya dilakukan saat pindah rumah dari kampungnya atau mengganti dengan rumah baru atau karena malapetaka. Kehadiran para peserta pada kegiatan membongkar rumah karena adanya malapetaka dilakukan secara spontanitas tanpa adanya rencana dan pemberitahuan lebih dahulu. Pada kegiatan membongkar rumah, pekerjaan pertama adalah menurunkan atap rumah yaitu genteng atau seng, baru kemudian reng dan tiang. Adapun dindingnya telah dilakukan lebih dahulu sebelum menurunkan atap.

Kegiatan kerjasama tolong-menolong dalam mendirikan dan membongkar rumah memberikan manfaat bagi pemilik rumah, selain menciptakan keakraban, tanggung jawab sosial pun telah dilaksanakan. Kehadiran para famili dan kerabat menandakan adanya ikatan kekeluargaan yang kuat. Kehadiran para tetangga menandakan pula bahwa hubungan bertetangga baik dan ikatan sekampung menjadi lebih kuat. Bagi mereka yang tidak ikut, seakanakan ada perasaan berhutang budi. Demikian juga halnya pada kegiatan membongkar rumah, apa lagi kalau membongkar rumah itu karena adanya malapetaka.

Adapun gotong royong tolongmenolong dalam bidang perkawinan, bisa terlihat dalam beberapa kegiatan yakni Nyani kubu, yaitu kegiatan kerjasama tolong menolong dalam membuat tarup yang dilakukan oleh laki-laki dewasa dan bujang, dengan jumlah 10 sampai 15 orang. Ngakuk hibas, yaitu kegiatan kerjasama dalam mencari daun enau muda yang akan digunakan baik sebagai perlengkapan upacara maupun bahan untuk membuat lepet. Ngerang, yaitu kegiatan kerjasama menumbuk padi yang dilakukan kaum ibu atau gadis. Tandang, yaitu mencari keperluan pesta yang bahannya berada dalam hutan yakni mencari kayu bakar, kegiatan ini dilakukan oleh laki-laki. Melawai, yaitu kegiatan kerjasama mencari ikan di sungai. Ngebebak kubu, atau ngabungkar kubu, yaitu kegiatan membongkar tarup. Memasak untuk keperluan pesta yang dilakukan 5 hari sebelum prosesi upacara, dilakukan oleh para istri penyimbang dan ipar perempuan dari istri kakaknya. Perkawinan bagi masyarakat Lampung, demikian juga Desa Negara Nabung bukan hanya merupakan urusan pribadi, tetapi merupakan urusan kerabat dan famili bahkan termasuk status atau derajat.

Oleh sebab itu semua dikerjakan secara bersama-sama mulai dari persiapan sampai pelaksanaan upacara adat perkawinan. Satu minggu sebelum pelaksanaan upacara, keluarga melaksanakan suatu musyawarah (perwatin) bersama dengan pemimpin adat (penyimbang). Mereka membicarakan segala sesuatu tentang pelaksanaan upacara. Kegiatan memasak biasanya dilakukan oleh para ibu yang dikoordinir oleh istri penyimbang. Adat Lampung mengharuskan kegiatan memasak diatur oleh bebai mirul yakni kelompok para istri penyimbang dan kaum ibu yang berhak dan berkewajiban mengatur wanita menurut jenjang kedudukan suami masing-masing. Dalam upacara adat mirul, semua perempuan yang bersuami dengan perkawinan pembayaran jujur, berkewajiban bekerja di dapur untuk menyiapkan makanan. Dalam pekerjaan tersebut dibantu oleh para suaminya yang disebut dengan mengiyan.

Kegiatan gotong royong tolongmenolong dalam perkawinan juga terlihat pada sumbangan uang atau barang yang diberikan kepada pemilik hajat. Tetangga sekitar memberi kayu bakar yang nantinya untuk keperluan memasak, masing-masing memberi satu gerobak kayu bakar yang diangkut sendiri. Tetangga sekitar pada umumnya memberi sumbangan (ngejuk) berupa uang berkisar Rp.50.000,00, namun untuk keluarga dekat biasanya memberi uang dan barang yakni kebutuhan pokok seperti beras, gula, mie, sayur- mayur, ayam, dan kambing. Semua pemberian ini dicatat untuk kemudian dikembalikan lagi (bales) jika yang memberi sumbangan tersebut punya hajat perkawinan. Ngejuk adalah istilah masyarakat Negara Nabung berarti memberi sumbangan, bales adalah istilah yang berarti membalas lagi, dan kebimbangan adalah istilah yang berarti bergantian. Jadi gotong royong tolongmenolong di bidang perkawinan dilakukan secara kebimbangan (bergantian) atau resiprositas (timbal balik). Arisan perkawin- 
an juga diadakan di Desa Negara Nabung, yakni arisan berupa barang keperluan upacara seperti sembako, ayam atau kambing. Peserta arisan tidak banyak, biasanya masih ada hubungan keluarga.

Jika ada musibah kematian, dibunyikan beduk $2 \mathrm{x}$ untuk laki-laki dan $3 \mathrm{x}$ untuk perempuan. Pukulan ini disebut gebuk sesah, dengan mendengarkan bunyi beduk yang demikian itu, warga kampung mengetahui bahwa ada orang yang meninggal dunia. Warga masyarakat secara spontan mencari berita dan pergi melayat. Pada umumnya, kaum wanita yang datang melayat membawa beras dan sekarang ada yang membawa uang disebut selawat. Selawat adalah uang duka yang diberikan kepada keluarga almarhum. Terdapat kebiasaan bila ada yang meninggal, tokoh masyarakat atau pimpinan adat (penyimbang) menyuruh beberapa orang untuk menggali kubur dan memandikan mayat. Pekerjaan menggali kubur dilakukan oleh warga, akan tetapi sekarang ini ada yang mulai menggunakan tenaga upah (penggali kubur). Semua tata cara upacara kematian berdasarkan ketentuan agama Islam, mulai dari memandikan, mengkafankan, menguburkan, dan mendoakan jenazah di mesjid.

Demikianlah kegiatan gotong royong dalam bidang kematian, warga secara spontan begitu mendengar ada orang yang meninggal dunia langsung pergi melayat. Jika ada warga yang terkena musibah, baik meninggal dunia maupun sakit atau tertimpa kesedihan, warga datang untuk menjenguk atau melayat, sebagai rasa solidaritas dan simpati kepada orang yang terkena musibah tersebut dan mereka memberikan selawat (uang duka).

Selain gotong royong tolongmenolong, masyarakat Negara Nabung juga melakukan gotong royong kerja bakti yang bertujuan untuk kepentingan bersama. Dengan kata lain, kegiatan gotong royong kerja bakti ini dilakukan untuk kepentingan bersama, misalnya untuk membuat irigasi sawah, kebersihan kampung, mendirikan mesjid, jalan, sesat, dan makam.
Masyarakat Negara Nabung pada dasarnya mengenal gotong royong kerja bakti ngunggak way yakni memperbaiki bendungan irigasi, agar airnya dapat masuk melalui saluran air menuju ke sawah. Adapun peserta dalam kegiatan ini adalah para pemilik sawah yang bersatu dengan tujuan yang sama yakni memperbaiki irigasi agar sawahnya subur dan panen berlimpah. Kegiatan ngunggak way pada prinsipnya hanya diikuti oleh kepala keluarga pemilik sawah yang memerlukan air dari irigasi tersebut. Apabila kepala keluarga tidak dapat hadir, maka ia harus mengirimkan wakilnya. Namun demikian, kepala kampung walau ia tidak memiliki sawah harus ikut memimpin kegiatan ini. Kegiatan gotong-royong kerja bakti nunggak way ini dilaksanakan apabila musim tanam tiba. Apabila ada pemilik sawah yang tidak ikut serta dan tidak mengirimkan wakilnya, maka diharuskan memberi ketupat satu bakul sebagai denda karena tidak ikut serta dalam kegiatan tersebut. Sebelum kegiatan gotong royong kerjabakti ngunggak way dilaksanakan, malam harinya diadakan pemberitahuan melalui pengumuman keliling kampung dengan metuk canang (memukul gong kecil). Pada pagi hari mereka membawa cangkul dan perlengkapan lain untuk membuat bendungan dan talang air yang oleh masyarakat Negara Nabung disebut kekerung (Jawa = gorong-gorong).

Adapun kegiatan gotong royong kerjabakti pada pembangunan masjid dan sesat (rumah adat tempat berkumpul) dikerjakan bersama-sama (abir), mulai dari membuat fondasi sampai memasang batu bata dan atap. Pada taraf berikutnya pekerjaan tidak lagi dikerjakan secara gotong royong kerja bakti tetapi menggunakan tukang bangunan khusus karena membutuhkan keahlian. Dahulu, kegiatan mengumpulkan bahan bangunanan dikerjakan secara gotong royong, tetapi sekarang diperoleh dengan cara membeli dan warga hanya memberi bantuan (sumbangan) berupa uang. Kegiatan gotong royong kerja bakti dalam membangun masjid, pada dasarnya merupakan kewajiban setiap anggota masya- 
rakat. Oleh karena itu dalam kegiatan tersebut tidak dirasakan sebagai beban, tetapi telah menjadi kewajiban sosial. Namun demikian, walaupun telah dirasakan sebagai kewajiban sosial, apabila ada warga yang tidak bisa ikut dalam kegiatan tersebut tidak ada sanksi apa-apa. Hanya secara psikologis, warga yang tidak ikut merasakan ada beban tanggung jawab dan kurang enak hati.

Demikian pula dalam membangun atau memperbaiki jalan (rurung) biasanya dilakukan bersama-sama dengan kesadaran tinggi, karena untuk kepentingan bersama sebagai alat transportasi. Setiap kampung, terdapat beberapa jalan (rurung) yang terdiri atas jalan utama (pokok) yang disebut dengan rurung agung, yaitu jalan adat utama. Ada yang diberi nama rurung way yaitu jalan adat yang dilalui untuk upacara, jalan rurung talang yaitu jalan yang dilalui arak-arakan upacara. Membangun jalan baru dengan cara swadaya masyarakat, kecuali jalan utama (rurug agung) dilakukan oleh pemerintah. Mereka mengadakan iuran melalui jimpitan beras yang tiap hari wajib memberi 1 sendok makan beras untuk tiap keluarga. Jimpitan beras diambil tiap minggu sekali pada hari Jumat dan kemudian dikumpulkan di mesjid. Hasil dari penjualan beras akan digunakan untuk kepentingan umum, seperti memperbaiki jalan atau membuat jalan baru. Dalam pembuatan jalan, khususnya jalan adat utama yang disebut rurung agung harus diperhatikan letaknya. Jalan adat utama pada dasarnya adalah jalan yang terletak di depan bangunan sesat. Adapun rurung way terletak berdekatan dengan way atau sungai. Pembuatan jalan baru ini biasanya dipimpin oleh para penyimbang dan tokoh masyarakat dibantu oleh para ibu dan remaja khusus untuk menyediakan makanan. Sementara lelaki biasanya mengangkut pasir dan batu sebagai bahan tambahan pembuatan jalan yang sering dilakukan pula pada malam hari, karena siang hari mereka bekerja di kebun.

Pembuatan dan pemeliharaan jalan juga diatur secara bergilir, yang menurut istilah setempat disebut kalirang laya. Kalirang laya adalah kerja bakti membuat jalan yang sudah diatur secara bergilir agar jalan terpelihara dengan baik. Kegiatan ini biasanya dipelopori oleh pimpinan formal dan nonformal (penyimbang atau ketua adat). Peserta dari kegiatan ini melibatkan tiap kepala keluarga dari kampung yang memperoleh giliran untuk memperbaiki jalan. Tujuan dari kegiatan ini adalah memperbaiki jalan rusak dan membersihkan jalan. Kepala keluarga atau wakilnya dari kampung yang memperoleh giliran harus datang dengan seorang penyimbang (kepala adat). Tiap kampung memperoleh giliran dua kali dalam setahun. Bagi kepala keluarga yang tidak ikut dan tidak mengirimkan wakilnya, akan kena denda memberi sejumlah uang atau makanan.

Demikianlah, pada umumnya kegiatan gotong royong pada masyarakat Negara Nabung sudah menjadi adat kebiasaan yang sudah dilakukan leluhur sejak dahulu sampai sekarang. Peran ketua adat, dalam hal ini para penyimbang dan sistem kekerabatan yang berdasarkan garis keturunan dari bapak (patrilinial geneologis), berakibat pula pada kegotongroyongan di Negara Nabung. Penyimbang sebagai ketua adat mempunyai peranan cukup besar, yakni mengatur jalannya adat; mengambil keputusan adat; sebagai mediator pemerintah dalam pembangunan; menyelesaikan berbagai persoalan sosial masyarakat, seperti adanya konflik dan memimpin upacara adat. Sebagai tokoh masyarakat, penyimbang juga sangat disegani, dihormati, dan sebagai tempat bertanya dalam segala hal. Bahkan, pemimpin formal sering melibatkan para penyimbang dalam pelaksanaan programprogram pembangunan, karena terkadang imbauan penyimbang lebih didengar warga daripada pemerintah.

Desa Negara Nabung terdapat 41 tokoh adat (penyimbang) yang tergabung dalam forum MPAL yakni Majelis Perwatin Adat Lampung. Struktur organisasi MPAL terdiri atas ketua, sekretaris, bendahara, dan anggota. Fungsi dari forum ini adalah sebagai ajang komunikasi antartokoh adat, penghubung masyarakat dengan pemerintah, dan pencari solusi berbagai masalah adat dan sosial. Besarnya pengaruh penyimbang ini memberi dampak yang positif bagi masyarakat, yakni sebagai penggerak dan motivator dalam setiap kegiatan adat maupun sosial. Demikian pula dalam hal 
kegotongroyongan, baik tolong-menolong maupun kerja bakti, sosok penyimbang bisa digunakan sebagai simbol penggerak masyarakat. Sebagai pemimpin adat, penyimbang selalu hadir dalam setiap kegiatan gotong royong. Oleh sebab itu, masyarakat juga tergerak untuk ikut kegiatan tersebut, meskipun sebenarnya bukan karena figur penyimbang melainkan juga karena kesadaran sendiri.

Sistem kekerabatan berdasarkan patrilineal juga akan melahirkan hak dan kewajiban dalam bermasyarakat, terutama dalam persoalan perkawinan. Kedudukan laki-laki memegang kekuasaan tertinggi yang bertanggung jawab sebagai pemimpin keluarga, orang tua, adik-adiknya, dan sanak famili. Ia mengatur hak dan kewajiban adikadiknya, baik pria maupun wanita dan semua keluarganya. Pendek kata yang berfungsi sebagai pengatur adalah kerabat pria (ayah), sedang kerabat dari pihak wanita hanya membantu. Hal ini tentu akan berakibat pula dalam hal tolong-menolong menyelesaikan pekerjaan yang memerlukan bantuan tenaga dan dana. Jika adiknya menikah misalnya, kakak laki-laki harus membantu dana untuk pelaksanaan upacara yakni membeli sesan (alat-alat rumah tangga untuk pengantin). Demikian pula para ipar, yakni istri kakak laki-laki ikut membantu memasak, dari persiapan sampai prosesi upacara.

Selain pengaruh kepenyimbangan dan sistem patrilineal, ikatan gotong royong tolong-menolong juga dipengaruhi oleh kekerabatan berdasarkan hubungan darah dan perkawinan. Mereka harus saling membantu dan bekerja sama dalam semua persoalan, terutama masalah adat. Namun demikian, keluarga ayah merupakan pokok utama dalam menangani pekerjaan berat yang sudah diatur secara adat. Hubungan kekerabatan atas dasar kepenyimbangan, mengatur bahwa rumah keluarga batih hanya merupakan keluarga bilik dari rumah besar, tempat kepala adat dan para sesepuh (mertua, nenek) tinggal. Dengan sendirinya jika anggota kepenyimbangan memerlukan bantuan, tentu seluruh anggota keluarga serumah harus membantu untuk menyelesaikan pekerjaan tersebut.

Sementara itu di Desa Negara Nabung, terdapat aktivitas gotong royong di bidang ekonomi dalam bentuk arisan, ada arisan rumah, arisan rumah tangga, arisan lebaran, arisan pertanian, arisan hajatan, arisan mingguan, arisan bulanan, dan arisan kampung. Arisan rumah tangga berupa barang-barang rumah tangga; arisan lebaran berupa bahan pokok untuk kue dan masakan lebaran; arisan rumah berupa material; arisan pertanian berupa pupuk dan modal; arisan hajatan berupa hewan sapi kambing dan ayam; arisan mingguan dan bulanan berupa uang. Berbagai arisan ini merupakan bentuk gotong royong ekonomi yang ditujukan untuk membantu anggotanya mendapatkan modal, menyelesaikan masalah ekonomi, dan meringankan beban yang dihadapinya. Arisan, termasuk juga KUD dan kelompok tani yang ada di Desa Negara Nabung merupakan lembaga ekonomi ma-syarakat yang mengatur anggotanya untuk memenuhi kebutuhan hidupnya.

Ngejuk, bales, sambatan, selawat, dan kebimbangan adalah istilah yang mencerminkan sikap gotong-royong masyarakat Desa Negara Nabung. Ngejuk adalah istilah masyarakat Negara Nabung berarti memberi sumbangan; bales berarti membalas lagi; dan kebimbangan berarti bergan-tian; selawat merupakan uang duka yang diberikan kepada orang yang terkena musibah (kematian, sakit). Jadi gotong royong tolong-menolong di bidang perkawinan dilakukan secara kebimbangan (bergantian) atau resiprositas (timbal balik), ngejuk, selawat, dan bales. Dalam suatu perhelatan perkawinan, tradisi menyumbang merupakan salah satu aktivitas berantai. Maksudnya jika merasa disumbang, kelak akan berganti menyumbang (resiprokal), begitu pula sebaliknya. Perkawinan bukan saja menjadi urusan pribadi, tetapi juga menjadi urusan para kerabat, bahkan dirasakan sebagai kewajiban dan tanggung jawab dari anggota atau masyarakat dari kampung yang bersangkutan. Oleh 
sebab itu, semua dikerjakan secara bersamasama, mulai dari persiapan sampai pelaksanaan upacara adat perkawinan.

Hasil yang diperoleh dalam aktivitas gotong royong tersebut, tentu akan meringankan biaya, waktu, dan tenaga bagi si empunya hajat. Pekerjaan besar dan berat akan menjadi lebih ringan dan lebih cepat diselesaikan. Selain itu, menumbuhkan rasa kebersamaan, yang pada akhirnya menimbulkan kerukunan sosial. Bagi warga yang membantu pun sangat diuntungkan, karena mereka mendapat imbalan baik bentuk materi maupun nonmateri. Artinya, suatu saat kelak akan mendapat bantuan meskipun tidak ada pamrih. Sistem sumbangmenyumbang merupakan rangkaian kegiatan yang penting dalam suatu peristiwa perhelatan, dan merupakan kewajiban sosial yang tidak bisa ditinggalkan. Dalam aktivitas menyumbang terkandung 3 kegiatan, yakni memberi, menerima, dan membalas. Pranata yang berlaku mewajibkan individu melaksanakan ketiga hal tersebut, jika tidak akan mendapat sanksi sosial. Ketiga aktivitas tersebut memperkuat hubungan antarindividu dan kelompok. Dalam tradisi sumbang-menyumbang tersembunyi norma-norma timbal balik yang menjadi daya pengikat dalam satu jalinan sosial yang tidak ada habisnya dari generasi ke generasi.

\section{Perubahan Gotong Royong}

Demikianlah, kegiatan gotong royong di Desa Negara Nabung masih cukup kuat dilaksanakan oleh masyarakat. Namun demikian, tidak dipungkiri pada masa sekarang bentuk gotong royong mengalami perubahan akibat dari perkembangan teknologi, industrialisasi, dan modernisasi. Perubahan merupakan ciri khas semua masyarakat dan semua kebudayaan, baik masyarakat tradisional maupun modern. Hanya bedanya, pada masyarakat modern perubahan itu cukup cepat, sedangkan pada masyarakat tradisional perubahan itu lambat. Demikian pula yang terjadi pada aktivitas gotong royong di Desa Negara Nabung, terdapat perubahan yakni dahulu dilaksanakan gotong royong tetapi sekarang tidak lagi dilaksanakan.
Kegiatan gotong royong dalam membuka hutan sudah mulai jarang dilakukan, disebabkan banyak hutan yang berubah menjadi perkampungan bagi para transmigran. Akibatnya pada pohon kayu jati dan tanaman lain menjadi berkurang. Hal itu pula membawa dampak berkurangnya kegi-atan gotong royong dalam mencari kayu di hutan untuk pembuatan rumah, masjid, dan sesat. Dengan masyarakat mengenal uang dan dipasarkannya bahan-bahan bangunan, memberi pengaruh sehingga masyarakat tidak bergotong royong mencari kayu di hutan dengan melewati laut atau sungai (ngelandau kayu), tetapi membeli kayu dengan cara iuran (membuat masjid, sesat), membeli sendiri di toko (membuat rumah) atau menanam sendiri di kebun.

Perubahan juga terlihat dalam bidang pertanian, di Desa Negara Nabung hanya sebagian kecil yang bercocok tanam di sawah, sebagian besar mereka di ladang (kebun) dengan menanam singkong dan pisang. Hal itu disebabkan sistem irigasi di sawah (pengairan) tidak berjalan lancar, sehingga hanya mengandalkan tadah hujan dengan panen 2 kali dalam setahun. Mereka lebih banyak bertanam singkong, karena singkong merupakan tanaman yang cukup menjanjikan bagi masyarakat Negara Nabung. Satu hektar lahan mampu menghasilkan uang 10 sampai 15 juta rupiah dan bisa dipanen 2 kali dalam setahun. Jenis singkong yang ditanam khusus untuk pembuatan tepung tapioka, yakni kasesa dan thailand. Selain singkong, pisang juga ditanam masyarakat, karena mudah ditanam, tidak ada hama, dan bisa menghasilkan pendapatan cukup banyak.

Sistem upah dalam bidang pertanian yang dahulu diperoleh berupa nyakai, yakni meminjam hasil yang sudah mereka kerjakan dan kelak akan dikembalikan dalam jumlah yang sama, sekarang diganti dengan sistem bagi hasil 10:1 atau 6:1. Bahkan, sekarang ada sebagian yang sudah menggunakan upah berupa uang. Demikian pula dalam mengolah tanah yang biasanya dilakukan dengan tenaga kerbau, saat ini sudah menggunakan tenaga mesin (traktor). Bentuk rumah yang berubah tidak lagi rumah panggung melainkan semi 
modern, berdampak juga pada aktivitas gotong royong. Mereka lebih memerlukan tenaga ahli untuk membangun rumah tersebut, akibatnya aktivitas gotong royong sudah jarang dilakukan.

Dalam bidang upacara adat perkawinan, batok ngarang yakni kegiatan menumbuk padi sudah jarang dilakukan karena diganti dengan huler (mesin penggiling padi). Demikian pula melawai (mencari ikan di sungai), sudah mulai jarang dilakukan, karena makin tersedianya ikan di pasar dan ada bahan pengganti yakni ayam dan daging sapi.

\section{Gotong Royong Sebagai Nilai Budaya}

Terlepas dari perubahan yang terjadi, namun sikap gotong royong pada masyarakat Negara Nabung masih cukup kuat melekat. Hal itu disebabkan di Desa Negara Nabung terdapat prinsip sakai sembayan, salah satu prinsip hidup masyarakat Lampung yang berarti tolongmenolong. Sakai sembayan adalah nilai penting dalam kehidupan masyarakat Negara Nabung. Nilai-nilai budaya pada dasarnya terdiri atas konsepsi yang hidup dalam alam pikiran sebagian besar warga masyarakat, mengenai hal-hal yang harus mereka anggap bernilai dalam hidup. Oleh karena itu, nilai-nilai budaya biasanya berfungsi sebagai pedoman tertinggi bagi kelakuan manusia. Dengan demikian, nilainilai pada kegotongroyongan pada hakikatnya merupakan perwujudan dari kebudayaan.

Setiap masyarakat, betapapun sederhananya pasti mempunyai kebudayaan. Oleh karena itu, J. Herkovits dan Broinislaw Malinowski menyatakan bahwa segala sesuatu yang terdapat di dalam masyarakat ditentukan oleh adanya kebudayaan yang dimiliki oleh masyarakat itu. Dalam hubungannya dengan gotong royong, pada dasarnya merupakan pengejawantahan dari nilai-nilai budaya yang bersumber pada kebudayaan suatu masyarakat.

Dengan demikian, gotong royong yang dimiliki masyarakat Negara Nabung, merupakan pengejawantahan dari nilai-nilai budaya yang menjadi pandangan hidup masyarakat Lampung, yakni piil pesenggiri dengan didukung prinsip yang lain yakni nemui-nyimah, nengah nyappur, dan bujuluk buadek, yang berarti harga diri, tolongmenolong, menghormati atau saling hormat, dan bertata hidup atau bergelar.

Dari pandangan hidup tersebut, dapat dikatakan bahwa gotong royong merupakan penjelmaan dari pandangan hidup. Hal ini pula yang menjiwai keikutsertaan anggota masyarakat dalam berbagai kegiatan, baik untuk kepentingan perorangan (tolong-menolong) maupun untuk kepentingan umum (kerja bakti). Dari pandangan hidup tersebut dapat dikatakan bahwa dengan melakukan gotong royong terjelma kerukunan di dalam pergaulan hidup masyarakat. Bila dikatakan bahwa kerukunan merupakan genus, gotong royong merupakan spesies yang merupakan suatu bentuk dari proses interaksi sosial yang tradisional sifatnya. Menurut Keesing (1989:162) hal ini disebabkan : (1) Manusia itu tidak cukup sendiri di dunia ini, tetapi dilingkungi oleh komuniti, masyarakat, dan alam semesta sekitarnya; (2) Dengan demikian, manusia pada hakikatnya bergantung pada aspek kehidupannya kepada sesamanya; (3) Oleh karena itu ia selalu berusaha sedapat mungkin memelihara hubungan baik dengan sesamanya, terdorong jiwa sama rasa; dan (4) Selalu berusaha untuk sedapat mungkin bersifat konform, berbuat sama dengan sesamanya dalam komuniti, terdorong oleh jiwa sama tinggi sama rendah. Dengan demikian, untuk menciptakan dan memelihara kerukunan sesama warga, kerabat dan famili, anggota komuniti, serta memenuhi hasrat kemanusiaan, maka tercipta kerjasama, baik bertujuan untuk menolong maupun untuk berbakti.

\section{Masa Depan Gotong Royong}

Setiap masyarakat selama hidupnya, pasti mengalami perubahan. Perubahan di dalam masyarakat dapat mengenai semua segi kehidupan, seperti nilai-nilai, norma- 
norma, dan pola-pola perilaku. Apabila kerangka ini diterapkan dalam konsepsi gotong royong, tentu akan mengalami perubahan juga. Untuk dapat menelaah, bagaimana masa depan gotong royong, disampaikan suatu analisis yang diberikan oleh Niel J. Smelser (Keesing, 1989:132). Dia menyatakan bahwa disebabkan oleh ide pembangunan ekonomi ini telah menjadi sangat biasa dalam pandangan pertengahan abad ke-20, kita dapat dengan mudah menganggapnya sebagai suatu proses yang sederhana dan utuh. Akan tetapi pembangunan ekonomi tidaklah sederhana dan utuh. Sekurang-kurangnya ada empat proses dalam pikiran kita: (1) Dalam bidang teknologi, suatu masyarakat yang berkembang sedang mengalami perubahan dari penggunaan teknik-teknik yang sederhana dan tradisional ke arah penggunaan pengetahuan ilmiah; (2) Dalam bidang pertanian, masyarakat yang berkembang itu sedang beralih dari pertanian sederhana ke arah produksi hasil pertanian untuk pasaran. Ini berarti pengkhususan dalam jenis tanaman yang akan dijual hasilnya, pembelian barang-barang nonpertanian di pasaran, dan sering juga kerja upahan dalam bidang pertanian; (3) Dalam bidang industri, masyarakat yang sedang berkembang mengalami suatu peralihan dari penggunaan tenaga manusia dan binatang ke indutrialisasi yang sebenarnya, atau orang-orang yang berkerja untuk upah pada mesin-mesin yang digerakkan oleh sumber tenaga; (4) Dalam susunan ekologi perkembangan masyarakat bergerak dari sawah/ladang dan desa ke pemusatanpemusatan di kota.

Dari apa yang di ketengahkan di atas, nyata sekali bahwa beberapa fungsi dari tenaga manusia, diambil alih teknologi dan menimbulkan sistem upah, sehingga satu atau lebih dari anggota keluarga meninggalkan keluarganya untuk mencari pekerjaan dalam pasaran tenaga kerja. Implikasi sosial dari perubahan struktur yang dilukiskan tadi adalah terjadinya proses individualisasi dan isolasi keluarga batih, maka akan memperlonggar hubungan kekerabatan.

Dalam hubungannya dengan masa depan gotong royong, kiranya perlu diperhatikan dan dapat dijadikan indikator untuk menentukan tentang masa depan. Dengan adanya perkembangan teknologi dan modernisasi, tentu ada pergeseran nilainilai budaya dan pandangan hidup. Berdirinya 2 pabrik tepung tapioka yang ada di Desa Negara Nabung, menyebabkan banyak kaum muda yang bekerja sebagai buruh pabrik. Hal ini membawa implikasi berkurangnya tenaga kerja yang melakukan aktivitas gotong royong di pertanian. Hasil penelitian menunjukkan bahwa pada saat sekarang telah terjadi perubahan, dalam arti bahwa suatu bentuk kegiatan yang tadinya dilakukan secara kerja sama, menjadi tidak dilakukan lagi.

Hal tersebut di atas menunjukkan bahwa pada masa yang akan datang gotong royong akan lebih mengalami perubahan lagi. Perubahan ini akan mungkin terjadi meskipun secara lambat atau pelan. Suatu contoh, dahulu ada sistem bagi hasil dalam panen tapi sekarang dengan sistem upah. Ini menandakan ada upah masuk dan unsur gotong royong menjadi berkurang. Oleh karena itu dapat dimengerti apabila Koentjaraningrat menyatakan bahwa telah terjadi perubahan sistem gotong royong dalam bidang pertanian menjadi sistem upah. Bahkan ada bentuk gotong royong yang sudah punah, menghilang dari kehidupan sosial masyarakat.

Kiranya pernyataan itu tidak hanya terbatas dalam bidang pertanian saja, tetapi juga dalam bidang lain. Sebagai contoh dalam hal kematian, kalau dahulu ada warga yang membantu menggali kubur, tapi sekarang ada tukang gali kubur. Jadi unsur gotong royong melemah, mengarah pada sistem upah dengan adanya tenaga-tenaga tertentu yang diminta bantuannya dan diberi imbalan, biasanya berupa uang.

Perubahan yang terjadi memang tidak bisa dihindari, namun tetap optimis bahwa nilai gotong royong masih kuat melekat terutama pada masyarakat pedesaan. Hasil identifikasi dan kajian di Desa Negara Nabung menunjukkan bahwa kegiatan gotong royong masih tetap dilakukan meskipun ada juga yang sudah tidak dilakukan. Sistem nilai sangat sulit berubah dan selalu hidup dalam alam pikiran manusia serta dijadikan pedoman hidup. Adanya prinsip hidup piil pesinggiri, sistem 
kekerabatan yang berdasarkan patrilineal, dan aturan adat, menjadikan pengikat dan kontrol sosial pada masyarakat untuk tetap melakukan aturan-aturan (gotong royong) yang sudah berlaku.

\section{PENUTUP}

Gotong royong Di Desa Negara Nabung, secara umum masih tetap dilakukan dalam kehidupan sehari-hari yakni di bidang mata pencaharian, pertanian, upacara adat, membangun rumah, jalan, mesjid dan lainlain. Ada beberapa faktor penyebabnya mengapa tetap dilakukan. Pertama, peran ketua adat dalam hal ini para penyimbang mempunyai pengaruh kuat sebagai motivator masyarakat, termasuk dalam menggerakkan masyarakat untuk melaksanakan gotong royong. Kedua, sistem kekerabatan berdasarkan garis keturunan dari bapak (patrilineal geneologis). Sistem ini akan melahirkan hak dan kewajiban dalam bermasyarakat, Kedudukan laki-laki memegang kekuasaan tertinggi dan bertanggung jawab sebagai pemimpin keluarga, termasuk membantu keluarga (bergotongroyong) dalam semua persoalan hidup. Kedua, memiliki prinsip hidup yang mengharuskan manusia berwatak dan berperilaku luhur, yakni punya harga diri (piil pesenggiri), harus bergotong royong (sakai sambaian), membuka diri (nemui nyimah), suka bergaul (nengah nyapur), dan punya nama gelar (bejuluk deadek). Keempat, aturan adat dalam sistem kekerabatan berdasarkan hubungan darah dan perkawinan. Aturan ini mengharuskan untuk saling membantu diantara keluarga. Empat faktor tersebut memperkuat sebagai kontrol sosial pada masyarakat agar mereka tetap patuh dalam melaksanakan aturanaturan yang berlaku (gotong royong).

Ngejuk, bales, sambatan, selawat, dan kebimbangan adalah istilah yang mencerminkan sikap gotong-royong masyarakat Desa Negara Nabung. Ngejuk adalah istilah masyarakat Negara Nabung berarti memberi sumbangan; bales berarti membalas lagi; dan kebimbangan berarti bergantian; selawat merupakan uang duka yang diberikan pada orang yang terkena musibah (kematian, sakit), dan sambatan adalah bantuan tenaga. Tradisi sumbang menyumbang dalam suatu perhelatan itu sudah merupakan kewajiban sosial yang harus dilakukan, ada 3 kegiatan yakni memberi, menerima, dan membalas. Dalam tradisi ini tersembunyi norma-norma timbal balik yang jadi pengikat dalam jalinan sosial yang tidak ada habisnya dari generasi ke generasi.

Tidak bisa dipungkiri, gotong royong saat ini mengalami perubahan disebabkan oleh proses industrialisasi, teknologi, dan modernisasi. Perubahan merupakan ciri khas semua masyarakat dan kebudayaan, demikian pula gotong royong di Desa Negara Nabung, dalam arti dulu dikerjakan sekarang tidak lagi. Namun, gotong royong sebagai nilai budaya tampaknya cukup sulit untuk berubah karena nilai budaya ini terdiri atas konsepsi atau hal-hal yang dianggap paling penting dalam hidupnya dan berfungsi sebagai pedoman hidup. Gotong royong ini merupakan penjelmaan dari pandangan hidup tersebut (piil pesenggiri). Hasil identifikasi dan kajian yang dilakukan di Desa Negara Nabung menunjukkan bahwa mereka masih melakukan aktivitas gotong royong dalam kehidupan sehari-hari.

Bila dikaitkan dengan pembangunan, gotong royong ini merupakan modal sosial yang menunjang proses pembangunan. Walaupun gotong royong mulai melemah, itu hanya bentuk luarnya yang berubah, tapi nilai-nilai kerja sama masih mengakar kuat di sanubari masyarakat. Itu sebabnya tetap optimis dan yakin bahwa nilai-nilai kerja sama dan gotong royong ini selalu hidup di masyarakat.

\section{Saran}

Desa Negara Nabung yang terletak di Kecamatan Sukadana Kabupaten Lampung Timur, merupakan daerah yang cukup kuat menjalankan aktivitas kerja sama gotong royong. Gotong royong sudah 
menyatu dengan kehidupan masyarakatnya. Sakai sambaian (gotong royong), salah satu prinsip hidup (falsafah) orang Lampung memberi nafas dan tercermin dalam kehidupan sehari-hari. Namun demikian diperlukan langkah-langkah nyata untuk memperkuat dan mengaktifkan kembali, antara lain :

1. Gotong royong perlu disosialisasikan dan ditingkatkan aktivitasnya, terutama pada generasi muda karena memiliki nilai-nilai kebersamaan dan kerukunan.

2. Gotong royong bisa digunakan sebagai modal sosial untuk mendukung proses pembangunan.

3. Peranan tokoh adat (penyimbang) dan tokoh masyarakat bisa dilibatkan untuk proses pembangunan, karena mereka memiliki peran besar sebagai penggerak masyarakat dalam melaksanakan aktivitas gotong royong.

4. Gotong royong sangat perlu dipertahankan, agar hubungan sosial terjalin dengan baik dan tujuan pembangunan tercapai. Namun demikian ada beberapa hal yang disesuaikan dengan perkembangan zaman, seperti misalnya tenaga hewan diganti dengan traktor untuk membajak tanah sawah agar lebih meningkatkan produktivitas pertanian.

\section{DAFTAR SUMBER}

Ahima-Putra, H.S. 2002.

Budaya Lokal Sebagai Sumber Penataan Sosial". Makalah dalam Temu Budaya Daerah di PPPG Matematika, 5-6 Agustus 2002. Yogyakarta : Balai Kajian Sejarah dan Nilai Tradisional. 2007

"Organisasi Sosial Lokal di Indonesia". Makalah dalam Bimbingan Teknis Penelitian. Jakarta: Direktorat Tradisi.
2004

Jejak Masa Lalu. Sejuta Warisan

Budaya. Yogyakarta: Kunci Ilmu.

Haryono, T. 2002.

"Peran Budaya Lokal dalam

Pranata Sosial". Makalah dalam

Temu Budaya Daerah, di PPPG

Matematika, 5-6 Agustus 2002.

Yogyakarta: Balai Kajian Sejarah dan Nilai Tradsional Yogyakarta.

Koentjaraningrat. 1981.

Beberapa Pokok Antropologi

Sosial. Jakarta: Dian Rakyat.

1982.

Kebudayan, Mentalitet dan

Pembangunan. Jakarta: Gramedia

1984.

Kebudayaan Jawa. Jakarta: Balai

Pustaka

Keesing, RM. 1989.

Antropologi Budaya, Suatu

Perspektif Kontemporer. Jakarta:

Erlangga

Rudito. 2007.

"Organisasi Sosial". Makalah pengarahan penelitian organisasi sosial. Jakarta: Direktorat Tradisi.

Sentoso,P. 2003.

"Pengelolahan Modal Sosial dalam Rangka Pengembangan Otonomi Daerah: Suatu Tantangan”. Dinamika Pedesaan dan Kawasan.

Sumintarsih. 2010.

Pranata Sosial di Lingkungan Masyarakat Ponorogo (Sebuah Gambaran Budaya di Desa Sumoroto). Yogyakarta: Patrawidya 